\title{
Rancang Bangun Alat Sadap Elektrik untuk Tanaman Karet
}

\author{
Joga Dharma Setiawan*, Arman Purwiantoro, Gunawan Dwi Haryadi, Munadi, Mochammad Ariyanto \\ Departemen Teknik Mesin, Fakultas Teknik, Universitas Diponegoro \\ Jl. Prof. Sudharto, SH., Tembalang-Semarang 50275, Telp. +62247460059 \\ *E-mail: joga.setiawan@ft.undip.ac.id
}

\begin{abstract}
Rubber is a very important plantation commodity in Indonesia. Approximately 3.2 million hectares of total rubber plantation area exist in Indonesia. The process of tapping rubber trees is still using manual tapping tool using human power. In this research, electric rubber tapping device is designed as a new innovation for rubber plant rubber aged 6 to 10 years. Manufacture of rubber tapping tool is done such a way by slightly modifying the manual tapping tool and considering the availability of components on the market with the aim to facilitate the production in large quantities. Electric rubber tapping machine aims to support farmers in doing their work and can increase rubber production from rubber trees. With a rotation speed of 130 RPM blades is expected to produce latex or rubber latex more than manual tapping equipment. From the initial test, the electric tapping knive had a longer slicing time whis was between 15 to 17 seconds while the time slicing using a manual blade took 7 to 8 seconds. Therefore, further modification and and development is necessary to improve farmers' performance in using electric rubbber knivel.
\end{abstract}

Keywords : Electric rubber tapping device, prototype, latex

\begin{abstract}
Abstrak
Karet merupakan komoditas perkebunan yang sangat penting peranannya di Indonesia. Sekitar 3,2 juta hektar total luas lahan kebun karet yang dimiliki oleh Indonesia. Proses penyadapan pohon karet hingga saat ini masih menggunakan alat sadap karet manual dengan menggunakan tenaga manusia. Dalam penelitian ini alat sadap karet elektrik dirancang sebagai inisiasi pengembangan untuk penyadapan tanaman karet umur 6 sampai 10 tahun. Pembuatan alat sadap karet elektrik menyesuaikan alat sadap karet manual dan ketersediaan komponen yang ada di pasaran dengan tujuann mempermudah produksi dalam jumlah besar. Pembuatan alat sadap karet elektrik bertujuan untuk mempermudah petani dalam melakukan pekerjaannya serta dapat meningkatkan produksi karet dari pohon karet. Dengan kecepatan putar pisau 130 RPM diharapkan mampu menghasilkan latex atau getah karet yang lebih banyak dari alat sadap karet manual. Dari hasil pengujian awal pisau sadap elektrik mempunyai waktu mengiris yang lebih lama yaitu antara 15 - 17 detik sedangkan waktu mengiris menggunakan pisau manual membutuhkan waktu $7-8$ detik. Untuk itu perlu modifikasi dan pengembangan lanjutan untuk meningkatkan kinerja petani dalam menggunakan pisau sadap elektrik.
\end{abstract}

Kata kunci: Alat sadap karet elektrik, prototipe, latex

\section{Pendahuluan}

Beberapa wilayah di Indonesia memiliki keadaan lahan yang cocok untuk penanaman karet, sebagian besar berada di wilayah Sumatera dan Kalimantan. Luas area perkebunan karet tahun 2005 tercatat mencapai lebih dari 3,2 juta ha yang tersebar di seluruh wilayah Indonesia. Di antaranya $85 \%$ merupakan perkebunan karet milik rakyat, dan hanya $7 \%$ perkebunan besar negara serta $8 \%$ perkebunan besar milik swasta. Produksi karet secara nasional pada tahun 2005 mencapai 2,2 juta ton [1]. Luas areal selanjutnya disusul Thailand (2,1 juta ha), Malaysia (1,3 juta ha), China (0,6 juta ha), India (0,6 juta ha), dan Vietnam (0,3 juta ha). Dari areal tersebut diperoleh produksi karet Indonesia sebesar 2,3 juta ton yang menempati peringkat kedua di dunia, setelah Thailand dengan produksi sekitar 2,9 juta ton. Posisi selanjutnya ditempati Malaysia (1,1 juta ton), India ( 0.8 juta ton), China ( 0,5 juta ton), dan Vietnam ( 0,4 juta ton) [2]. Perkebunan nusantara/negara yang mengusahakan tanaman karet berjumlah 11 dari 14 perkebunan. Luas total lahan kebun karet 362.600 ha yang terdiri dari kebun sendiri 206.800 ha dan mengelola plasma petani 155.800 ha [3]. Tenaga kerja untuk menyadap tanaman karet semakin berkurang karena pegawai tetap sudah memasuki masa pensiun. Saat ini semakin sulit mendapatkan tenaga penyadap. Menyadap tanaman karet merupakan pekerjaan yang berat dan membutuhkan keterampilan. Persyaratan dalam menyadap yaitu mampu mengontrol konsumsi kulit per hari sadap dan kedalaman sadapan yang tidak sampai merusak jaringan kayu $[4,5,6,7]$.

Alat untuk menyadap tanaman karet berupa pisau sadap. Pisau sadap dipergunakan untuk mengiris kulit karet 1,5 
mm sepanjang setengah spiral batang tanaman karet. Setelah kulit terpotong pembuluh getahnya maka akan keluar getah atau lateks selama tekanan turgor tinggi dan pembuluh lateks tidak tersumbat atau terjadi penggumpalan. Pisau sadap dioperasikan secara manual yaitu ditarik oleh tenaga penyadap. Pisau sadap berbentuk lepengan logam yang bagian ujung terdapat bengkokan $50^{\circ}-60^{\circ}$ dan bagian pangkal dipasangkan tangkai kayu untuk pegangan penyadap. Panjang pisau sadap pada umumnya sekitar $20-25 \mathrm{~cm}$.

\section{Dasar Teori}

\subsection{Tanaman Karet}

Tanaman karet adalah tanaman tahunan yang dapat tumbuh sampai umur 30 tahun. Tanaman ini merupakan pohon dengan tinggi tanaman dapat mencapai 15 - 20 meter, memiliki sifat gugur daun sebagai respon tanaman terhadap kondisi lingkungan yang kurang menguntungkan (kekurangan air atau musim kemarau) dan akan tumbuh kembali pada awal musim hujan. Tanaman karet juga memiliki sistem perakaran yang ekstensif atau menyebar cukup luas, sehingga tanaman karet dapat tumbuh pada kondisi lahan yang kurang menguntungkan.

Tanaman karet (Hevea brasiliensis) memiliki masa belum menghasilkan sebelum lima tahun (masa TBM 5 tahun). Tanaman karet akan dapat dipanen getahnya pada usia 5 tahun dan memiliki usia produktif sampai 25-30 tahun. Buah karet berbentuk kotak tiga/empat. Setelah berumur 6 bulan buah akan masak dan pecah sehingga biji karet terlepas dari batoknya. Biji karet terdiri dari 40-50\% kulit yang keras, bewarna coklat, 50-60\% karnel yang bewarna putih kekuningan. Kernel biji karet mengandung minyak 40-50\%, 2,71\% abu, 3,71\% air, 22,17\% protein dan $24,21 \%$ karbohidrat. Ini menunjukan bahwa biji karet berpotensi untuk menjadikan sumber minyak nabati. Tetapi kandungan air yang cukup besar dalam biji dapat memicu hidrolisis trigliserida menjadi FFA. Biji karet merupakan limbah pertanian yang tidak mempunyai nilai ekonomi, tidak memerlukan lahan subur, pemeliharaan yang intensif dan ketersediaannya melimpah [3].

\subsection{Sistem Sadap Karet}

Penyadapan dilakukan dengan memotong kulit pohon karet sampai batas kambium dengan menggunakan pisau sadap. Jika penyadapan terlalu dalam dapat membahayakan kesehatan tanaman, dan juga untuk mempercepat kesembuhan luka sayatan maka diharapkan sadapan tidak menyentuh kayu (xilem) akan tetapi paling dalam 1,5 mm sebelum kambium dan dengan ketebalan sadapan sekitar 1,5 - $2 \mathrm{~mm}$.

Sadapan dilakukan dengan memotong kulit kayu dari kiri atas ke kanan bawah dengan sudut kemiringan 500- 600 dari horizontal dengan menggunakan pisau sadap yang berbentuk V. Semakin dalam sadapan akan menghasilkan banyak lateks. Pada proses penyadapan perlu dilakukan pengirisan. Bentuk irisan berupa saluran kecil, melingkar batang arah miring ke bawah. Melalui saluran irisan ini akan mengalir lateks selama 1-2 jam. Sesudah itu lateks akan mengental. Lateks yang yang mengalir tersebut ditampung ke dalam mangkok yang digantungkan pada bagian bawah bidang sadap. Sesudah dilakukan sadapan, lateks mengalir lewat saluran V tadi dan menetes tegak lurus ke bawah yang ditampung dengan wadah.

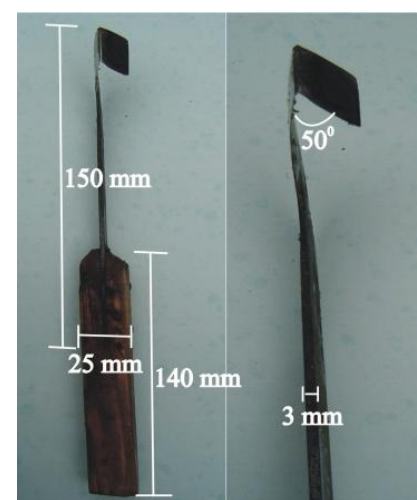

Gambar 1. Pisau sadap karet manual [5].

Waktu penyadapan yang baik adalah jam 5.00 - 7.30 pagi dengan dasar pemikirannya:

1. Jumlah lateks yang keluar dan kecepatan aliran lateks dipengaruhi oleh tekanan turgor sel.

2. Tekanan turgor mencapai maksimum pada saat menjelang fajar, kemudian menurun bila hari semakin siang.

3. Pelaksanaan penyadapan dapat dilakukan dengan baik bila hari sudah cukup terang.

Lateks adalah getah seperti susu dari banyak tumbuhan yang membeku ketika terkena udara. Ini merupakan emulsi kompleks yang mengandung protein, alkaloid, pati, gula, minyak, tanin, resin, dan gom. Pada banyak tumbuhan lateks biasanya berwarna putih, namun ada juga yang berwarna kuning, jingga, atau merah Untuk memperoleh hasil sadap yang baik, penyadapan harus mengikuti aturan tertentu agar diperoleh hasil yang tinggi, menguntungkan, serta berkesinambungan dengan tetap memperhatiakan faktor kesehatan tanaman agar tanaman dapat berproduksi secara optimal dan dalam waktu yang lama. 


\subsection{Produk}

Produk didefinisikan sebagai keluaran (output) yang didapat dari suatu proses produksi (transformasi) dan merupakan pertambahan nilai dari bahan baku (material input) dan merupakan komoditi yang dijual perusahaan kepada konsumen. Proses transformasi akan menyebabkan perubahan bentuk dan dimensi fisik dari material input serta sifatsifat material lainnya sesuai dengan rancangannya. Proses transformasi ini baru akan berarti positif apabila diikuti dengan adanya pertambahan nilai dari output yang dihasilkan baik berupa pertambahan nilai fungsional maupun ekonomi [6].

\subsection{Perancangan dan Pengembangan Produk}

Perancangan produk pada dasarnya merupakan sebuah langkah strategis untuk bisa menghasilkan produk - produk industri yang secara komersial harus mampu dicapai, guna menghasilkan pengembalian modal (rate of investment). Ukuran sebuah perancangan produk tidak hanya dilihat dari aspek teknis semata, melainkan harus memenuhi kriteria dalam hal nilai tambah ekonomisnya.

Untuk memberikan jaminan agar sebuah rancangan produk mampu memenuhi harapan diperlukan analisa dan evaluasi yang didasarkan pada metode pendekatan tekno- ekonomi. Tiga fungsi yang paling penting bagi proses pengembangan produk yaitu $[8,9]$ :

1. Pemasaran

Pemasaran berfungsi menjembatani interaksi antara perusahaan dengan pelanggan, peranan lainnya adalah memfasilitasi proses identifikasi kebutuhan pelanggan, menetapkan target harga, merancang peluncuran serta promosi produk.

2. Perancangan

Perancangan berfungsi dalam mendefinisikan bentuk fisik produk agar dapat memenuhi kebutuhan pelanggan, mencakup design engineering (mekanik, ergonomi, dan lain- lain)

3. Manufaktur

Proses manufaktur bertanggung jawab untuk merancang dan mengoperasikan sistem produksi pada proses produksi produk. Pengembangan produk merupakan keharusan bagi perusahaan untuk dapat mempertahankan kelangsungan hidupnya karena tidak ada satupun produk yang dapat bertahan selamanya. Hal yang membuat usaha pengembangan produk cukup menantang adalah:

a. Trade- off

Aspek pengembangan produk adalah mengetahui, memahami, dan mengendalikan pertentangan (trade- off) dalam rangka memaksimalkan kesuksesan produk.

b. Dinamika

Merupakan teknologi pengembangan produk baru dari pesaing lingkungan makro ekonomi yang selalu berubah.

c. Detail

Mencakup pemilihan komponen yang tepat pada suatu produk sehingga menghemat biaya yang cukup besar atau meningkatkan profit.

d. Tekanan waktu (time pressure)

Kesulitan dapat diatasi dengan mudah jika tersedia waktu yang cukup dalam proses pengembangan produk harus diambil dengan cepat tanpa informasi yang kurang lengkap.

Terdapat aktivitas produksi lain selain perancangan dan pengembangan suatu produk yang akan melibatkan penanganan pengendalian kualitas, mulai dari pengawasan bahan baku, bahan produksi, sampai barang jadi. Pengendalian kualitas sebagai pengendalian inspeksi atas karakteristik kualitas produksi yang akhirnya didapat kualitas produksi yang tinggi. Data- data yang diperoleh dari tanggapan responden akan mendasari suatu proses perancangan dan pengembangan suatu produk atau alat, sehingga didapatkan suatu perkiraan tentang sebuah hasil karya yang diinginkan pemakai guna meningkatkan produktivitas dan efektivitas kerjanya. Yang mana nantinya alat yang dibuat tersebut memiliki berbagai macam keunggulan dari pada produk yang telah ada dipasaran dan sesuai dengan apa yang selama ini diharapkan pemakai.

Dapat disimpulkan dibutuhkan kerjasama dari pihak lain dalam perancangan dan pengembangan produk untuk meningkatkan suatu barang atau jasa tidak dapat dilakukan sendiri, untuk mengatur dan mengkombinasikan sehingga diperoleh suatu produk yang diinginkan, seperti halnya mesin, bahan, manusia, dan lain- lain [9].

\subsection{Konsep Koefisien Gesek}

Gaya Gesek adalah gaya yang berlawanan arah dengan arah gerak benda. Gaya ini terjadi karena sentuhan benda dengan bidang lintasan akan membuat gesekan antara keduanya saat benda akan mulai bergerak hingga benda bergerak. Besarnya gaya ini ditentukan berdasarkan kekasaran permukaan kedua bidang yang bersentuhan, jadi semakin kasar permukaan suatu bidang maka nilai gaya geseknya akan semakin besar [4].

Gaya gesekan yang bekerja di antara dua permukaan dalam keadaan diam dikenal sebagai gaya gesek statis. Gaya gesek statis adalah gaya yang diperlukan untuk memulai pergeseran. Begitu geseran dimulai, gaya gesek biasanya akan 
berkurang pada tingkat tertentu yaitu untuk mempertahankan gerakan pergeseran. Gaya gesekan yang bekerja diantara dua permukaan pada gerakan relatif dikenal sebagai gaya gesek kinetik. Hubungan antara gaya F dengan gaya FN yang bekerja dalam arah normal pada permukaan kontak dinyatakan dengan:

$\mathrm{F}=\mu . \mathrm{FN}$

dimana: $\mu$ adalah koefisien gesekan statis atau dinamis [5].

\subsection{Motor Listrik}

Motor listrik merupakan perangkat elektromagnetis yang mengubah energi listrik menjadi energi mekanik. Energi mekanik ini digunakan untuk, misalnya memutar impeller pompa, fan atau blower, menggerakan kompresor, mengangkat bahan,dll. Motor listrik digunakan juga di rumah (mixer, bor listrik, fan angin) dan di industri. Motor listrik kadangkala disebut "kuda kerja" nya industri sebab diperkirakan bahwa motor-motor menggunakan sekitar $70 \%$ beban listrik total di industri [6].

\subsection{Electronic Speed Controler (ESC)}

Istilah ESC singkatan dari electronic speed control adalah rangkaian elektronik yang digunakan untuk mengubah kecepatan motor listrik, rutenya dan juga melakukan rem dinamis. Alat ini sering digunakan pada model yang dikendalikan radio yang bertenaga listrik, ESC paling sering digunakan untuk motor brushless dan pada dasarnya memberikan sumber tegangan listrik tiga fase elektronik untuk motor. Tetapi alat tersebut bisa juga digunakan untuk motor brushed seperti pada Gambar 2 [10].

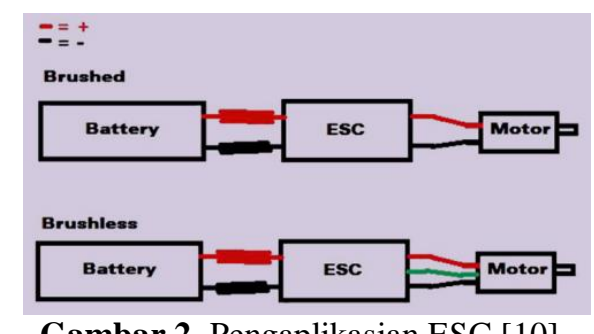

Gambar 2. Pengaplikasian ESC [10].

Untuk menentukan ESC yang akan digunakan sangatlah penting untuk mengetahui kekuatan (peak current) dari motor. Pilihlah ESC yang kekuatannya melebihi kekuatan motor. Misalnya, dari data didapatkan kekuatan motor adalah 12A (sesuai dengan datasheet motor) pada saat throttle terbuka penuh. Sebaiknya ESC yang akan digunakan adalah ESC yang berkekuatan 18A atau 20A. Jika dipaksakan menggunakan ESC 10A kemungkinan ESC akan panas dan bahkan terbakar.

\subsection{Potensiometer}

Potensiometer merupakan resistor yang menggunakan tiga terminal dengan sambungan geser yang membentuk pembagi tegangan yang dapat di stel. Biasanya perangkat elektronika ini juga ada yang menggunakan dua terminal, sehingga nantinya salah satu terminal tetap dan terminal geser. Komponen yang satu ini berperan sebagai resistor variabel atau rheostat. Potensiometer disebut juga Variabel Resistor yaitu komponen elektronika yang masih masuk keluarga Resistor yang mempunyai resistansi yang dapat diatur. Meskipun masih termasuk Resistor tetapi bentuk dari Potensiometer berbeda jauh dengan bentuk resistor. Potensiometer akan berganti Resistansi dengan cara mengatur atau menggeser bagian pengatur dari Potensiometer tersebut. Komponen elektronika ini pada umumnya memiliki 3 kaki. Potensiometer biasa digunakan untuk pengatur tegangan atau resistansi suatu perangkat elektronik, misalnya sebagai pengatur Tone Control suatu perangkat audio dan masih banyak lagi yang lainnya.

\section{Pembahasan}

\subsection{Simulasi Pembebanan}

Untuk mengetahui kekuatan dari part pisau pada alat sadap elektrik, dilakukan pengujian menggunakan pendekatan metode elemen hingga. Pengujian menggunakan menggunakan software Ansys 15. Adapun asumsi yang digunakan dalam pengujian adalah sebagai berikut :

- Part pisau merupakan assembly dari part mata pisau berbentuk V, lingkaran penampang pisau, dan shaft.

- Pengujian menggunakan pembebanan $60 \mathrm{~N}$ yang didistribusikan secara transient ke mata pisau yang menyentuh permukaan sadap untuk umur pohon kayu sekitar 12 tahun seperti yang diperlihatkan pada gambar 3 [11].

- Pengujian dilakukan secara keseluruhan menjadi part pisau sadap karet elektrik.

- Material yang digunakan adalah besi galvanis dan stainless steel.

- Ukuran mesh yang digunakan adalah 0,49991 mm dengan jumlah nodal sebesar 21210 dan jumlah element 
sebesar 6828.

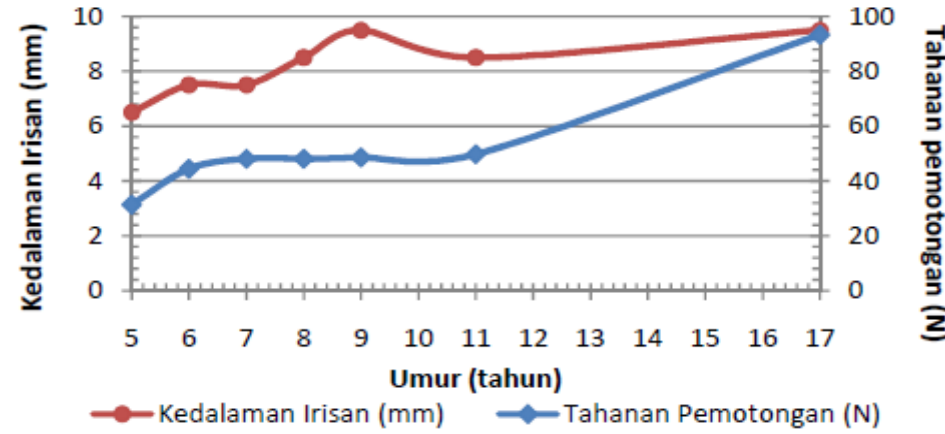

Gambar 3. Hubungan kedalam irisan dan tahanan pemotongan [11]

\subsection{Material}

Dalam pengujian ini, material yang digunakan untuk pembuatan part pisau dari alat sadap karet elektrik adalah besi galvanis dan stainless steel. Material besi galvanise digunakan pada part mata pisau yang berbentuk V. Tabel 1 menunjukkan mechanical properties besi galvanis yang digunakan untuk pengujian.

Tabel 1. Mechanical Properties besi galvanis.

\begin{tabular}{ll}
\hline Parameter & Nilai \\
\hline Density & $7870 \mathrm{~kg} / \mathrm{m}^{3}$ \\
Yield Strength & $203.9 \mathrm{MPa}$ \\
Poisson Ratio & 0.29 \\
Young's Modulus & $200000 \mathrm{MPa}$ \\
Tensile Strength & $356.9 \mathrm{MPa}$ \\
\hline
\end{tabular}

Sedangkan material stainless steel digunakan untuk lingkaran penampang part pisau V dan juga digunakan untuk pembuatan shaft pada part pisau. Tabel 2 menunjukkan mechanical properties dari stainless steel.

Tabel 2. Mechanical Properties dari stainless steel.

\begin{tabular}{ll}
\hline Parameter & Nilai \\
\hline Density & $7800 \mathrm{~kg} / \mathrm{m} 3$ \\
Yield Strength & $172,34 \mathrm{MPa}$ \\
Poisson Ratio & 0.28 \\
Young's Modulus & $200000 \mathrm{MPa}$ \\
Tensile Strength & $172,34 \mathrm{MPa}$ \\
\hline
\end{tabular}

\subsection{Hasil Pengujian}

Pengujian pada part pisau dengan memberi pembebanan transient pada permukaan yang menyentuh kulit pohon karet. Adapun arah pembebanan ditambpilkan pada Gambar 4.

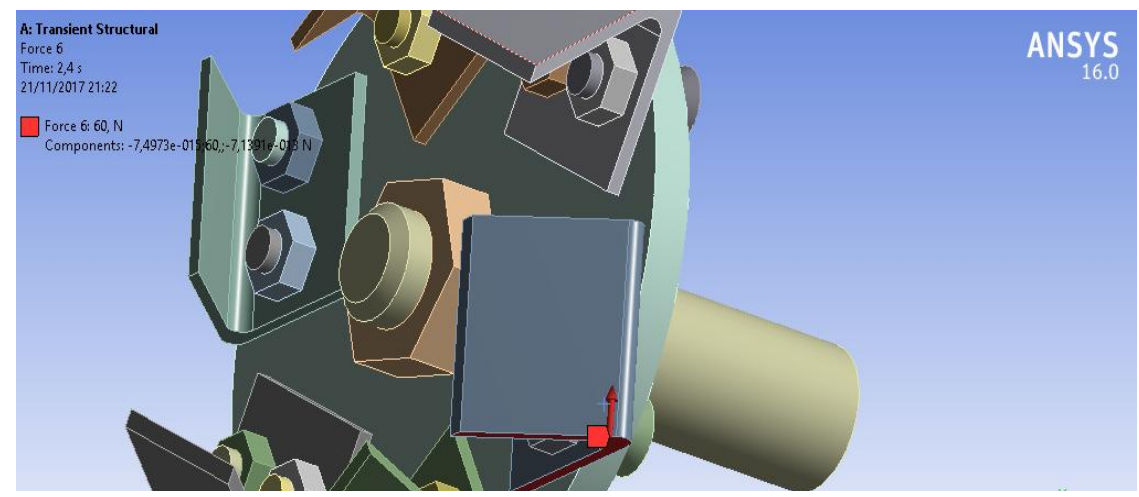

Gambar 4. Arah pembebanan pada part pisau.

Pemberian beban pada mata pisau adalah disesuaikan dengan tahanan pemotongan yang dimiliki oleh tanaman karet di umur 6 sampai 11 tahun. Diberikan beban transient pada setiap mata pisaunya, dan hasil dari pembebanan transient adalah seperti pada Gambar 5. Dari pengujian tersebut, total tegangan maksimum yang terjadi adalah 22,186 $\mathrm{MPa}$, maka didapatkan safety factor dari material besi galvanise adalah 9,19 dan nilai safety factor pada material 
stainless steel adalah 7,76.

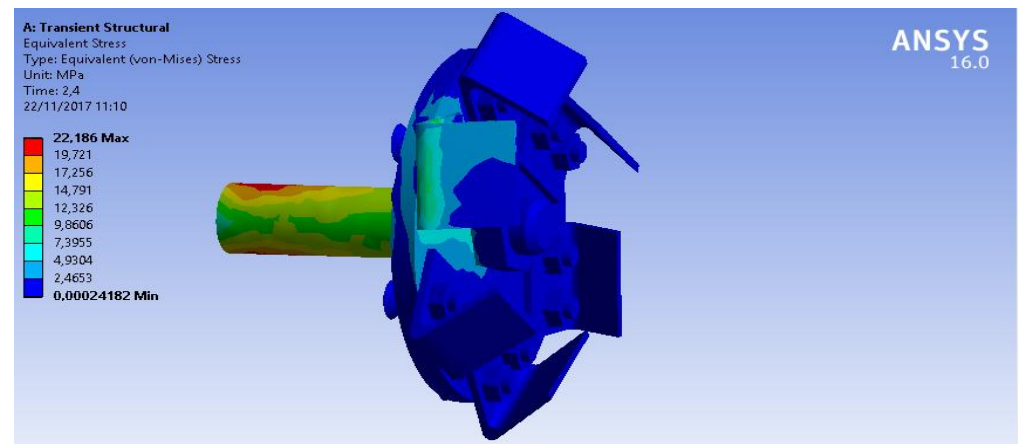

Gambar 5. Tegangan yang terjadi pada part pisau sadap karet elektrik.

\subsection{Prototipe Alat Sadap Elektrik untuk Tanaman Karet}

Hasil rancangbangun prototipe alat sadap karet elektrik untuk tanaman karet ditunjukan pada Gambar 6 dengan tambahan switch untuk mengubah putaran mata pisau counterwise atau counterclockwise.

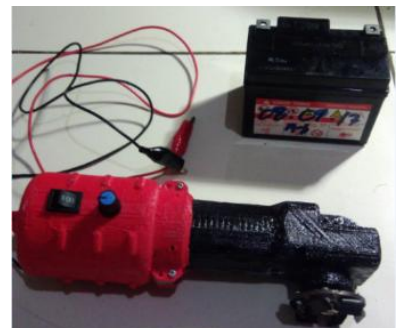

Gambar 6. Prototipe alat sadap elektrik untuk tanaman karet.

\section{Kesimpulan}

Pembuatan desain alat sadap elektrik menggunakan software solidworks 2015 dan pada part pisau dilakukan analisis menggunakan software ANSYS 16.0 dengan nilai total tegangan maksimum yang terjadi adalah $22,186 \mathrm{MPa}$. Part yang didapat dipasaran dalam pembuatan alat sadap elektrik yaitu DC motor, bevel gear, bearing, electronic speed controler, akumulator, mur, dan baut. Part yang dibuat dengan bantuan bengkel antara lain part pisau sadap dan casing alat sadap elektrik. Pisau sadap elektrik mempunyai waktu mengiris yang lebih lama yaitu antara 15 - 17 detik sedangkan waktu mengiris menggunakan pisau manual membutuhkan waktu $7-8$ detik.

\section{Referensi}

[1] Direktorat Jenderal Perkebunan, 2005. Statisitk Perkebunan Indonesia: Karet 2015-2017. http://ditjenbun.pertanian.go.id, Diakses 14 Desember 2017.

[2] Badan Penelitian dan Pengembangan Pertanian, Departemen Pertanian, 2007. Prospek dan Arah Pengembangan Agribisnis Karet. Edisi ke 2. http://www.litbang.pertanian.go.id, Diakses 15 Desember 2017.

[3] Anwar, C., 2006. Perkembangan Pasar dan Prospek Agribisnis Karet di Indonesia. Lokakarya Budidaya Tanaman Karet, 4-6 September 2006, Medan. https://www.scribd.com/doc/231079646/Perkembangan-Pasar-Dan-ProspekAgribisnis-Karet-Di-Indonesia, diakses 15 Desember 2017.

[4] Siregar., 1995, Teknik Penyadapan Karet, Kanisius, Yogyakarta.

[5] Wibowo, S.A., 2017. Disain Pisau Sadap Manual Untuk Mengoptimalkan Produksi Tanaman Karet (Hevea brasiliensis), Jurnal Penelitian Karet, 35(2): 179-188.

[6] Anwar, A. dan Anas, A., 1987. Teknologi Pengolahan Karet Spesifikasi Teknis. Makalah. Balai Penelitian Perkebunan Sungai Putih, Medan.

[7] Adri dan Supriyanto, J., 2009. Teknologi Penyadapan Tanaman Karet. Leafleat. Balai Pengkajian Teknologi Pertanian Jambi, http://www.bppjambi.info/dwnpublikasi.asp?id=179, diakses 14 Desember 2017.

[8] Ulrich, K.T., and Eppinger, S.D., 2001. Perancangan dan Pengembangan Produk. Edisi Ketiga, Salemba Teknika, Jakarta.

[9] Harsokoesoemo, H.D., 2004. Pengantar Perancangan Teknik. Perancangan Produk. Edisi Kedua. Penerbit ITB, Bandung.

[10] Agawal, T., 2018. Introduction to Electronic speed Controller (ESC) Working and Applications. https://www.elprocus.com/electronic-speed-control-esc-working-applications/, diakses 10 Agustus 2018.

[11] Suhermanto., 2011, Disain dan Kinerja Pisau Sadap Elektrik Untuk Tanaman Karet (Hevea brasiliensis), Institut Pertanian Bogor, Bogor. 